\title{
O novo Museu \\ de Arqueologia \\ e Etnografia
}

JOSÉ JOBSON DE ANDRADE ARRUDA

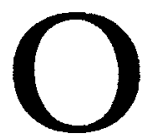

Museu de Arqueologia e Etnografia (MAE/USP) é uma das mais recentes unidades criadas no âmbito da Universidade de São Paulo, por iniciativa do Reitor José Goldemberg, através da resoluçáo no 3560, de 11 de agosto de 1989. De fato, trata-se de um novo Museu com velha história, pois resultou da fusão dos acervos arqueológicos e etnográficos do antigo Museu de Arqueologia e Etnografia do Instituto de Pré-História, do Acervo Plínio Ayrosa do Departamento de Antropologia da FFLCH e da maior parte do acervo do Museu Paulista, num expressivo conjunto que soma mais de 100 mil artefatos de indiscutível valor científico e cultural.

E extremamente abrangente o leque de culturas representadas neste conjunto: mediterrânicas e médio-orientais, africanas e afro-brasileiras, além de americanas. No que concerne ao Brasil, destacam-se as coleçóes etnográficas representativas de agrupamentos indígenas contemporâneos. Concretamente, o acervo constitui um repositório essencial à preservação da memória arqueológica, sustentando importantes trabalhos de pesquisa, alimentando a docência e transmutando-se em símbolos culturais preciosos à comunicação museológica. Define-se como um patrimônio cultural que, além de servir ao papel integrador dentro da Universidade, desborda esta funçáo ao interagir com a sociedade da qual é expressão e a quem deve propiciar elevação cultural.

A política relacionada com o acervo é fundamental para definir a vocação da instituição. $\mathrm{O} M A E$ não é apenas um Museu. É um Museu na Universidade e, portanto, deve cumprir a sua finalidade precípua como órgão de integração. Talvez seja a Universidade brasileira que mais longe caminhou no sentido de transformar os Museus em núcleos vivos dentro de seu organograma funcional. Nessa perspectiva, cabe ao MAE realizar o ciclo completo de atividades inerentes à vida acadêmica: pesquisa, ensino e extensão. Cabe-lhe ainda enfatizar o seu papel principal na extensão, o lado mais visível da interaçăo com a comunidade, que náo poderá se cumprir sem as pesquisas sustentadas pelo acervo e 
indispensáveis à sua própria ampliação, além das pesquisas museológicas vitais à comunicaçáo com o público que se deseja atingir, passando pelo ensino em variados níveis, que prepara a nova geração de pesquisadores e docentes.

Quase uma centena de pessoas desincumbem-se das tarefas que lhes são designadas. O MAE tem em seus quadros uma vintena de pesquisadores titulados nas áreas de Arqueologia, Etnologia e Museologia. Um número equivalente de técnicos especializados em documentaçáo, conservação e restauro, serviço educativo, museografia e especialistas em atividades de campo e de laboratório, além de amplo quadro de funcionários. Este universo de servidores públicos pôde reunir-se em um único prédio a partir de maio de 1993, local anteriormente pertencente ao BID-Fundusp e que, por determinação do então Reitor Roberto Lobo, foi reformado e ampliado para receber o novo MAE, numa área de aproximadamente $4.000 \mathrm{~m}^{2}$, que reúne pessoal e acervo outrora disperso no campus e fora dele.

O processo de concentração propiciou também a reunião dos acervos das várias bibliotecas especializadas em arqueologia, etnologia e museologia, formando a maior biblioteca do gênero no país, com cerca de 6.500 volumes, além de 1.700 títulos de periódicos. Para veicular a produçăo científica de seus pesquisadores e divulgar trabalhos de inegável mérito científico de pesquisadores nacionais e estrangeiros, 0 MAE edita a Revista do Museu de Arqueologia e Etnologia, que sucedeu as antigas publicações Dédalo, Revista de Pré-História e Anais do Museu Pautista (série arqueológica e etnológica).

Os pesquisadores do MAE estão envolvidos com as atividades docentes em seus vários níveis, organizando cursos de graduaçăo, extensão universitária e pós-graduação. Além da formação de mestres e doutores na pós-graduação, orientam estagiários, iniciação científica, especialização, sem contar os estagiários juntos às seçóes técnico-científicas dos serviços de Museologia, Curadoria e Educaçáo. Os Serviços Educativo e de Museologia desenvolvem vários projetos, individuais ou integrados, de atendimento a estudantes, de orientação aos professores, ministrando cursos sobre o aproveitamento didático de coleçóes museográficas. Realizam exposiçóes itinerantes, que são excelentes oportunidades para levar o Museu às escolas e ao público em geral.

Em função das amplas atividades desenvolvidas, formularam-se convênios com instituiçōes dentro e fora do Brasil, fundaçôes, prefeituras e empresas, visando a ampliar o espectro de atuaçăo do Museu na área de sua especialidade. Sendo o país um vasto laboratório arqueoló- 
gico, são freqüentes as solicitações para assessorias e consultorias que envolvem problemas de preservação ambiental e conservaçáo da memória histórica.

A unificação dos acervos acarretou, portanto, um efeito multiplicador. Criou uma massa crítica, em termos de acervo, em termos de pesquisadores, capaz de transformar pequenas unidades isoladas e frágeis no Museu mais importante de sua categoria no país, com uma insigne tarefa sobre seus ombros: a missão de subsidiar a compreensão do processo de formação cultural do Brasil, em suma a busca da definição de uma dupla identidade: do país e do próprio MAE.

Jost Jobson de Andrade Arruda foi diretor do Instituto de Pré-História de 1986 a 1989 e diretor do Museu Paulista de Arqueologia e Emografia de 1989 a 1994. 